\title{
LAS DECLARACIONES SIMBÓLICAS DE LOS MUNICIPIOS: ENTRE LA AUTONOMÍA LOCAL, EL «POSTUREO»INOCUO Y EL ABUSO
}

\author{
JUAN MARÍA MARTÍNEZ OTERO \\ Universidad de Valencia
}

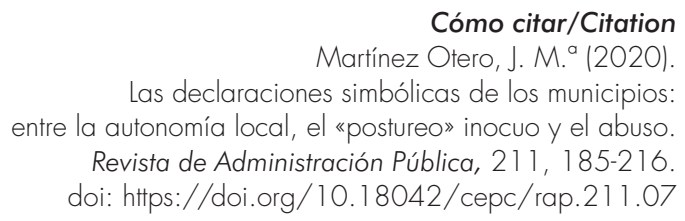

\section{Resumen}

El presente estudio aborda la legalidad de las declaraciones simbólicas municipales sobre cuestiones que no son propiamente de su competencia. En primer lugar, se presentan ejemplos de este tipo de declaraciones, y se aventuran algunas de las razones que las propician. En segundo lugar, se exponen y discuten los principales criterios utilizados por la jurisprudencia a fin de discernir cuándo una declaración simbólica resulta conforme con el ordenamiento jurídico y cuándo no. Finalmente, se ofrecen dos argumentos que invitan a embridar más decididamente la actividad declarativa de los municipios: la exigencia de neutralidad de la Administración, en relación con el principio de pluralismo y el mantenimiento de una opinión pública libre, y la ausencia de mandato representativo de los concejales para pronunciarse sobre cuestiones allende los intereses del municipio.

\section{Palabras clave}

Autonomía municipal; declaraciones simbólicas; actividad declarativa; municipio. 


\section{Abstract}

This paper addresses the legality of municipal symbolic declarations that deal with issues that fall outside their responsibility. First, it presents some examples of this type of statements, and discusses some of the reasons behind them. Secondly, the main case law related with these declarations is exposed and discussed. Finally, the paper offers two arguments that invite to be more restrictive with these symbolic declarations: the requirement of neutrality of the Administration, in relation to the principle of pluralism and the maintenance of a free public opinion; and the absence of representative mandate of the councilors to give their opinion on issues beyond the interests of the municipality.

\section{Keywords}

Municipal autonomy; Symbolic declarations; Declarative activity; Municipality. 


\section{SUMARIO}

I. INTRODUCCIÓN. II. MUESTRARIO. III. BREVE EXCURSUS: INDAGANDO EN LAS CAUSAS DE LAS DECLARACIONES SIMBÓLICAS. IV. CRITERIOS PARA DETERMINAR LA LEGALIDAD DE LAS DECLARACIONES SIMBÓLICAS: 1. La naturaleza de las declaraciones. 2. Los efectos de las declaraciones. 3. La autonomía de los municipios y los concejales. 4. La cuestión competencial. 5. El contenido de la declaración. V. APORTACIONES AL DEBATE: LA NEUTRALIDAD IDEOLÓGICA DE LA ADMINISTRACIÓN Y LA AUSENCIA DE MANDATO REPRESENTATIVO: 1. La neutralidad ideológica de la Administración y el respeto al pluralismo. 2. La ausencia de mandato representativo. VI. CONCLUSIONES.

\section{INTRODUCCIÓN}

Las declaraciones simbólicas de los municipios $-\mathrm{y}$ una cierta litigiosidad asociada a las mismas - no pasan de moda. A falta de estudios empíricos que respalden esta intuición, una mirada atenta a la actualidad municipal permite confirmar si no la creciente, al menos la periódica aprobación de declaraciones simbólicas o retóricas, mediante las que los Plenos municipales manifiestan su opinión sobre diferentes cuestiones de actualidad o que son objeto de debate público ${ }^{1}$.

Esta actividad declaratoria de los entes locales recae sobre materias de lo más variado, desde las innegablemente conexas con los intereses municipales hasta aquellas cuya relación con las competencias o intereses de la corporación local es más remota, cuando no directamente inexistente. Habitualmente, estos pronunciamientos revisten un carácter puramente declamatorio, aunque en ocasiones pueden conllevar algún tipo de efecto o consecuencia de carácter jurídico.

Si bien las declaraciones simbólicas distan mucho de ser una novedad en el panorama municipal, quizá en nuestras sociedades hiperconectadas los efectos

1 Entre nosotros, recientemente ha denunciado esta querencia declamatoria I. Villaverde Menéndez (2018), «¿Tienen opinión las instituciones políticas?», IDP, 18 de junio de 2018, disponible en: http://idpbarcelona.net/tienen-opinion-las-instituciones-politicas. 
de las mismas sí que pueden resultar novedosos. Y ello porque Internet y las tecnologías digitales permiten difundir las declaraciones simbólicas de forma casi ilimitada, multiplicando exponencialmente los potenciales efectos de las mismas.

Como es natural, cuando las declaraciones simbólicas de los municipios recaen sobre materias que son objeto de su competencia, nada cabe objetar a las mismas, siempre y cuando su contenido no contravenga el ordenamiento jurídico, claro está. Mayor interés jurídico revisten, en cambio, aquellas otras declaraciones que se ocupan de asuntos sobre los cuales el municipio carece de una competencia específica. Declaraciones estas más frecuentes, por cierto, toda vez que cuando el municipio tiene competencia sobre un asunto, habitualmente no se conforma con realizar declaraciones simbólicas sobre el mismo, sino que plasma su posición en medidas concretas, ya sean reglamentarias, prestacionales, de fomento, etc.

El presente estudio se propone analizar le legalidad de la actividad declaratoria de los municipios respecto de materias que no tienen expresamente atribuidas por el ordenamiento jurídico, con el fin de conocer cuándo dicha actividad constituye un ejercicio legítimo de la autonomía local, que hay que celebrar; cuándo supone una actividad cosmética, quizá prescindible y poco rigurosa, pero inocua y que, por lo tanto, es preciso tolerar; $y$, finalmente, cuándo resulta un abuso por parte de los representantes del municipio, que es necesario restringir.

Para ello, tras realizar una breve aproximación al fenómeno de las declaraciones simbólicas y explorar sucintamente las causas que propician su aprobación, se hace un repaso de los criterios empleados por la jurisprudencia para determinar la admisibilidad de este tipo de declaraciones. Identificados estos criterios, cuyo uso por el Tribunal Supremo ha sido marcadamente ambivalente, el artículo presenta dos argumentos que invitan a embridar más severamente esta actividad declaratoria: la exigencia de neutralidad de la Administración y la ausencia de mandato representativo de los concejales para ocuparse de cuestiones que no son competencia municipal.

\section{MUESTRARIO}

Antes de abordar el análisis jurídico de la cuestión planteada, resulta ilustrativo ofrecer un breve muestrario del tipo de declaraciones a las que nos vamos a referir, a fin de dar cuenta de su acusada heterogeneidad ${ }^{2}$.

Una primera categoría de acuerdos simbólicos — que casi podría calificarse de clásica - la conforman las declaraciones de persona non grata. Sin atisbo de exageración, puede afirmarse que «del rey abajo, ninguno» ha quedado a salvo de

2 Para no multiplicar innecesariamente las notas al pie, se ha optado por no referenciar cada uno de los acuerdos que en el presente epígrafe se mencionan. Una búsqueda sencilla en cualquier buscador de Internet ofrecerá al lector cumplida información sobre cada uno de ellos. 
esta forma de reprobación pública municipal. Entre las personas que han sido declaradas non gratas por entidades locales se encuentran el rey Felipe VI (Premià de Mar, 2016); expresidentes del Gobierno (Mariano Rajoy en Pontevedra, 2016); presidentes de naciones extranjeras (Donald Trump en Móstoles, 2018); alcaldes de otros municipios (el alcalde de Valladolid en Benidorm, 2010); cantantes (Manzanita en Alcalá de Henares, 1998); obispos (Xavier Novell en Cervera, 2017); empresas (Telefónica en Agüimes, 1998); cronistas municipales (Manuel Peláez en Priego, 1985); condenados por delitos sexuales (los miembros de «La Manada» en diversos municipios, como Cáceres o Sevilla, 2018); o incluso jueces por el contenido de sus votos particulares (así, el magistrado que propuso absolver a los integrantes de "La Manada» en Pozo de Guadalajara, 2018). El hecho de que los tribunales lleven veinte años declarando inválidas estas declaraciones no parece desalentar a los concejales de muchos municipios, que continúan recurriendo a esta fórmula manifiestamente ilegal para reprobar públicamente a ciertas personas objeto de su antipatía.

Con un contenido de lo más variado, también resultan habituales las declaraciones municipales promovidas por grupos políticos o de interés, que son replicadas de forma idéntica o muy similar en decenas o centenares de municipios. Veamos tan solo dos ejemplos. Desde el año 2010 más de setenta municipios españoles han aprobado acuerdos sumándose a la campaña «Boicot, Desinversiones y Sanciones: contra la colonización, el apartheid y la ocupación israelí» (en adelante, campańa BDS contra Israel), cuya finalidad es boicotear al Estado de Israel y sus cómplices por, siempre según sus impulsores, vulnerar reiteradamente los derechos humanos en Palestina. Recientemente, también ha hallado fortuna la declaración del municipio como «espacio libre de violencia de género», adoptada por decenas de municipios patrios desde el año 2016, como Huelva, Zalduondo o Totana, por poner tan solo tres ejemplos.

En los años 2012 y 2013 diferentes municipios catalanes aprobaron acuerdos municipales declarándose "territorio catalán libre y soberano», como Argentona, Vic, Piera, Cercs, Arenys de Munt o Caldes de Montbui.

En abril de 2018, el Ayuntamiento de Barcelona emitió una declaración institucional pidiendo la revisión de la sentencia del ya mencionado caso de «La Manada»; sostuvo que el fallo favorecía las agresiones machistas y solicitó al Congreso de los Diputados y al Senado la revisión del Código Penal.

A este brevísimo elenco cabría añadir un sinfín de acuerdos de la más variada índole: declaración de desnuclearización de un municipio y de protesta por la instalación de misiles nucleares en territorio europeo; hermanamiento con poblaciones pertenecientes a presuntos Estados no reconocidos por la comunidad internacional; declaración de emergencias climáticas; declaración como municipio «libre de desahucios», «libre de maltrato animal» o antitaurino; y un largo etcétera.

Como evidencian los ejemplos consignados, las declaraciones institucionales simbólicas suelen versar sobre asuntos conectados con la actualidad política o sobre causas de interés general que en un momento dado pasan a un primer 
plano en el debate público, lo que propicia una toma de posición por parte de los representantes del municipio.

\section{BREVE EXCURSUS: INDAGANDO EN LAS CAUSAS DE LAS DECLARACIONES SIMBÓLICAS}

La actividad declaratoria es una forma arraigada de participación municipal en debates de actualidad que, salvo en contadas ocasiones, ha sido pacíficamente admitida por jurisprudencia y doctrina. Sin ánimo de dar cuenta de todas las causas que propician el recurso a esta forma de actuación municipal, valga hacer un sucinto repaso de algunos de los motivos que la originan.

El motivo más claro, intuitivo y, si se quiere, puro, no es otro que la voluntad de los representantes de un municipio de tomar una posición activa y oficial respecto de una cuestión de interés público. Vistas bajo este prisma, las declaraciones institucionales se conciben como un acto de compromiso político de los concejales - y, por extensión, de todos los vecinos - con una determinada causa. En la medida en que los concejales son los representantes democráticos más próximos a la ciudadanía, cabría entender que estas declaraciones son un valioso canal de participación ciudadana ${ }^{3}$. En este sentido, las declaraciones institucionales podrían verse como una respuesta natural de los representantes de la corporación local a las exigencias de participación y al compromiso social de los vecinos de su municipio 4 .

En cualquier caso, no es oro todo lo que reluce, y quizá algunas declaraciones simbólicas responden a motivaciones más espurias.

En primer lugar, las declaraciones simbólicas pueden ser utilizadas a guisa de altavoz por parte de políticos interesados en hacer oír su voz en un foro público marcado por la infoxicación. La explosión de medios y canales que han generado Internet y las redes sociales ha mermado la visibilidad de los representantes políticos, al tiempo que ha reducido significativamente la eficacia de las formas más tradicionales a su alcance para influir en la opinión pública y conformar los comportamientos sociales 5 . En este contexto, no hay que excluir que el recurso a

3 J. Subirats (2016), El poder de lo próximo. Las virtudes del municipalismo, Madrid: Catarata (págs. 34-35).

4 Atendiendo a la crisis de participación y confianza en las instituciones políticas que todos los estudios de cultura política reflejan, esta primera hipótesis podrá ser tildada por algunos de ingenua. Sobre esta crisis de participación y los mecanismos al servicio de la participación vecinal, véase J. Martín Cubas (2016), «Democracia participativa en los entornos locales», en J. Noguera Tur (coord.), La visión territorial y sostenible del desarrollo local: una perspectiva multidisciplinar, vol. 2 (págs. 35-56), Valencia: Universitat de València (págs. 41 y ss).

5 Sobre el particular, resulta de interés L. M. Romero-Rodríguez y R. Mancinas-Chávez: «Sobresaturación informativa: visibilizar el mensaje institucional en tiempos de infoxica- 
las declaraciones simbólicas - tan fácilmente comunicables mediante un sucinto titular y una fotografía a través de Internet - responda a la voluntad de ciertos políticos de captar la atención y generar simpatía entre unos administrados y potenciales votantes cada vez más saturados de mensajes. Sin ánimo de sostener que dichas intenciones sean aviesas, sí parece claro que no resultan tan legítimas y generosas como el propósito de dar voz al sentir de los vecinos respecto de una determinada cuestión.

En segundo lugar, las declaraciones simbólicas pueden ser empleadas como arma política arrojadiza, a fin de obligar al rival político a posicionarse en relación con ciertos temas o debates de actualidad en los que quizá mantiene una posición impopular. Mientras que forzar al rival a retratarse públicamente respecto de cuestiones vinculadas con la política local es perfectamente legítimo, hacerlo en relación con asuntos totalmente ajenos a la gestión de los intereses municipales plantea más interrogantes. ¿Por qué exigir a un concejal de un municipio riojano que se posicione sobre la presunta violación de derechos humanos en la franja de Gaza? Quizá haya quien entienda que el escrutinio público de cualquier opinión política de los concejales —independientemente de su conexión con los asuntos municipales - resulta positivo y contribuye a una mayor representatividad del cuerpo electoral. Bien está. Lo que se pretende subrayar es que, a menudo, más que para plasmar la posición oficial del municipio sobre una cuestión, las declaraciones simbólicas tienen como finalidad principal situar en una posición comprometida a un rival político.

Finalmente, existen indicios para concluir que numerosas declaraciones simbólicas municipales obedecen a campañas orquestadas desde las cúpulas nacionales o autonómicas de ciertos partidos políticos, que se estarían aficionando a utilizar estas declaraciones como un canal más para la transmisión de sus mensajes y consignas. De ser así, so capa de una manifestación del sentir municipal — de comunicación bottom-up_-, las declaraciones constituirían una herramienta para incidir en la opinión ciudadana de forma up-bottom, aprovechando la proximidad de las instituciones locales.

\section{CRITERIOS PARA DETERMINAR LA LEGALIDAD DE LAS DECLARACIONES SIMBÓLICAS}

Una vez hemos dado cuenta de la casi inabarcable diversidad de las declaraciones simbólicas, y habiendo indagado en las posibles razones subyacentes a las mismas, procedemos a presentar los principales criterios utilizados por jurisprudencia y doctrina para determinar su legalidad.

ción», en Comunicación institucional y cambio social (págs. 111-138), Madrid: Ediciones Egregius. 
No espere el lector, empero, encontrar a continuación un conjunto de criterios unívocos conforme a los cuales emitir juicios generales sobre la admisibilidad de las declaraciones simbólicas. Como enseguida tendrá ocasión de constatarse, el empleo hecho por los tribunales de los criterios que se presentan ha sido acusadamente ambivalente, por no decir abiertamente contradictorio o errático.

Valga una última consideración previa a fin de dimensionar adecuadamente la cuestión que nos ocupa. La inmensa mayoría de declaraciones simbólicas nunca es objeto de impugnación ante la jurisdicción contencioso-administrativa. En efecto, la conflictividad en relación con las declaraciones simbólicas se limita a un reducido número de las mismas, normalmente por su conexión con debates particularmente sensibles —independencia de Cataluña_, o por afectar a la esfera de derechos o intereses de ciudadanos concretos — declaraciones de persona non grata — o de ciertos colectivos — campańas de boicot contra Israel—.

\section{LA NATURALEZA DE LAS DECLARACIONES}

Quizá la primera cuestión a determinar, a la hora de analizar jurídicamente una declaración simbólica, sea la de precisar su naturaleza jurídica.

Pues bien, respecto de esta primera cuestión ya existen pronunciamientos jurisprudenciales divergentes, que caracterizan las declaraciones de forma muy distinta: como actos administrativos, como actos estrictamente políticos, como un ejercicio del derecho de petición, como actuaciones de puro trámite o como actuaciones materiales ajenas al derecho. Como es lógico, en función de la caracterización por la que se opte, las posibilidades de declarar ilegal un acuerdo municipal variarán sustancialmente.

La jurisprudencia más proclive a declarar nulos los acuerdos simbólicos los caracteriza como verdaderos actos administrativos, sujetos a los límites materiales y formales previstos en el derecho administrativo y a una plena fiscalización judicial.

Si por acto administrativo entendemos, con García-Trevijano, cualquier «declaración unilateral de conocimiento, juicio o voluntad, emanada de una entidad administrativa actuando en su faceta de Derecho público, bien tendente a constatar hechos, emitir opiniones, crear, modificar o extinguir relaciones jurídicas, entre los administrados, o con la Administración, bien con simples efectos dentro de la propia esfera administrativa ${ }^{6}$, se impone la conclusión de que las declaraciones simbólicas son en puridad actos administrativos. Y ello porque,

6 J. A. González-Trevijano (1991), Los actos administrativos, Madrid: Civitas (págs. 96-97). Otras definiciones más clásicas de acto administrativo, como la sostenida por García de Enterría y Fernández, incluye en la definición el ejercicio de una potestad administrativa, extremo que resulta discutible que concurra en las declaraciones simbólicas. Véase E. García de Enterría y T.-R. Fernández (2002), Curso de Derecho Administrativo I, Madrid: Civitas (11 a ed.) (pág. 544). 
independientemente de sus efectos, consisten en declaraciones de juicio y en la emisión de opiniones aprobadas formalmente por un órgano administrativo tras un procedimiento reglado por el ordenamiento.

Así lo entiende, por ejemplo, la STS 4836/1998, de 17 de julio, caso persona non grata en Oleiros, que afirma que la declaración municipal «adopta la forma de un acto administrativo aprobado en forma por el Pleno del Ayuntamiento" ${ }^{7}$. En sentido similar, la STS 820/1987, de 9 de febrero, anula un acuerdo de desnuclearización del Ayuntamiento de Fernán Núñez, al estimar que el mismo, «al tratarse de un acuerdo adoptado por el Pleno del Ayuntamiento, constituye un acto de la Administración»" ${ }^{8}$. Más contundente si cabe es la STS 2088/2019, de 26 de junio, caso independencia Caldes de Montbui, que respecto de un acuerdo de respaldo al proceso independentista catalán, afirma: «[...] lo impugnado en el caso es un acto administrativo que, con independencia de su contenido político, sus efectos y su finalidad es, en forma evidente, susceptible de control judicial y ha de ser valorado en su conjunto»"

Pues bien, la consideración de las declaraciones institucionales como actos administrativos permite aplicarles estándares de control muy estrictos — fundamentalmente, criterios competenciales-, lo que determina en muchos casos su invalidez.

No obstante lo anterior, existe abundante jurisprudencia que niega que las declaraciones simbólicas sean actos administrativos, y se decanta por otras caracterizaciones que permiten aplicar a las mismas unos criterios de admisibilidad más benignos.

En primer lugar, las declaraciones han sido consideradas como actos de carácter político, adoptados en el ejercicio de la autonomía que la Constitución reconoce a los entes locales en los arts. 137 y 140.

En esta dirección apuntan diferentes pronunciamientos jurisprudenciales, como la STS 3994/1987, de 8 de junio, caso desnuclearización de Baracaldo. Respecto de uno de los puntos de la declaración, que manifestaba la oposición del municipio vizcaíno a la instalación de misiles nucleares en Europa, la sentencia afirma:

[...] el último de los puntos del acuerdo, el relacionado con el posicionamiento frente a la instalación de determinados misiles en Europa, no concretamente en Espańa, aunque no deja de ser una extralimitación respecto de las competencias establecidas para las Corporaciones Municipales [...] sólo constituye una postura ideológica respecto de tal cuestión, en realidad atinente tan sólo a los componentes

STS 8533/1998, de 17 de julio, FJ 20, caso persona non grata en Oleiros.

8 STS 820/1987, de 9 de febrero, FJ 2º caso desnuclearización Fernán Núńez. A similar conclusión llega, entre otras, la STS 595/1988, de 3 de febrero, caso desnuclearización de Leganés.

9 STS 2088/2019, de 26 de junio, FJ 8º, caso independencia Caldes de Montbui. 
de la Corporación que la han apoyado que, aunque discutible por su carácter subjetivo, es respetable $[\ldots]^{10}$.

La STS 1691/2008, de 23 de abril, caso adhesión de Llodio a la asociación de concejales Udalbiltza, rechaza el recurso contra la declaración municipal en términos análogos: "[...] en definitiva lo que se impugna es una actividad municipal [...] carente del contenido administrativo mínimo que la haría residenciable ante esta jurisdicción» ${ }^{11}$.

Esta caracterización de las declaraciones simbólicas como actos eminentemente políticos atiende fundamentalmente a que las mismas no despliegan efectos jurídicos. En palabras de Barata i Mir, estas declaraciones son "la expresión de un mero posicionamiento político por parte del supremo órgano democrático municipal, posicionamiento que no comporta acción o innovación normativa alguna, simultánea o posterior, en el ámbito jurídico-administrativo» ${ }^{12}$.

La caracterización de los acuerdos declamatorios como actos de carácter político reduce sustancialmente las posibilidades de control jurisdiccional sobre su contenido, conforme a lo dispuesto en el art. 2.a LJCA ${ }^{13}$.

En segundo lugar, existe una línea jurisprudencial que considera las declaraciones como un ejercicio del derecho de petición, reconocido con carácter general en el art. 29 de la Constitución. Este derecho, como es sabido, reconoce la posibilidad de dirigirse a los poderes públicos para formular una solicitud no fundamentada jurídicamente, cuyo otorgamiento tiene un carácter discrecional o graciable. Conforme a esta interpretación, cuando una corporación municipal realiza una declaración simbólica sobre una cuestión extramuros de sus competencias, lo que está haciendo — de forma implícita o explícita — es dirigir una petición en un determinado sentido a la Administración o poder público competente en la materia.

En los casos en que la declaración, en efecto, consista en una petición expresa a otra Administración o a otro órgano o poder constitucional, la caracterización del acuerdo como un ejercicio del derecho de petición no presenta grandes problemas, más allá de la cuestión — que no es baladí- sobre si una Adminis-

10 STS 3994/1987, de 8 de junio, FJ 5º, caso desnuclearización de Baracaldo.

11 STS 1691/2008, de 23 de abril, FJ 3º, caso adhesión de Llodio a asociación de concejales.

12 J. Barata i Mir (1999), Los actos de gobierno en el ámbito municipal, Madrid: Tecnos (pág. 88). En una línea similar, véase N. Garrido Cuenca (1998), El acto de Gobierno, Barcelona: Cedecs (págs. 595-596).

13 No es este el lugar para abordar el rico debate — en gran medida superado - en torno a la naturaleza de los actos políticos y a su posible revisión por los órganos jurisdiccionales. Baste con recordar que los actos políticos del gobierno son actos fundamentalmente discrecionales, por lo que los tribunales — conforme al art. 2.a LJCA— solo podrán fiscalizar algunos de sus elementos, sin entrar en valoraciones sobre su oportunidad. 
tración pública puede ser titular de derechos fundamentales ${ }^{14}$. Es más, algunos autores sostienen que el hecho mismo de que el Pleno de un municipio formule su declaración en términos de petición evidencia un reconocimiento implícito de su incompetencia y una manifestación de respeto deferente hacia las competencias ajenas ${ }^{15}$.

Ejemplo paradigmático de declaración reconducible al ejercicio del derecho de petición lo constituyen una serie de acuerdos de determinados ayuntamientos guipuzcoanos del año 1976, en los que solicitaban al rey la reintegración foral, la redacción de un Estatuto de Autonomía y la ceremonia del juramento de fueros. Los acuerdos fueron suspendidos por el gobernador civil de Pamplona, en el entendimiento de que su contenido era contrario al ordenamiento jurídico entonces vigente. Sin embargo, la Audiencia Territorial de Pamplona levantó la suspensión en diferentes sentencias de finales de 1976, señalando que los citados acuerdos constituían un legítimo ejercicio del derecho de petición ${ }^{16}$. Sobre un supuesto similar se pronuncia la STS 2921/1987, de 9 de febrero, caso desnuclearización de Valdoviño. A diferencia de otros acuerdos de desnuclearización adoptados por otros municipios, la declaración valdoviñesa consistía exclusivamente en una petición dirigida al gobierno de la nación, absteniéndose de ulteriores declaraciones de juicio o voluntad. En atención a ello, el Tribunal Supremo declaró el acuerdo admisible, en base a la siguiente argumentación: «[...] el acuerdo municipal impugnado ante la jurisdicción no declara ni adopta medidas de desnuclearización, de estricta competencia del Estado [...] sino que simplemente se acuerda dirigirse al Gobierno del Estado en petición de que sea éste quien las adopte, es decir, [...] tan solo se ejercita el derecho de petición amparado en el art. 29 de la Constitución para toda persona individual o colectiva» ${ }^{17}$.

14 Sobre el particular, resulta de interés: I. Lasagabaster (1991), «Derechos fundamentales y personas jurídicas de Derecho público», en S. Martín-Retortillo (coord.), Estudios sobre la Constitución Española, Homenaje al Profesor Eduardo García de Enterría, tomo II (págs. 651-674), Madrid: Civitas, y también: I. Torres Muro (2014), «Entes públicos y derechos fundamentales», Foro. Nueva época, 17-2, págs. 347-368.

15 Barata i Mir (1999: 102-105), y también: G. M. Díaz González (2019), «Nulidad radical de un Acuerdo municipal de apoyo al proceso soberanista catalán", Revista de Estudios de la Administración Local y Autonómica, 12, págs. 152-164 (pág. 162).

16 Comentando las sentencias de alzamiento de las suspensiones, apunta Leguina: «[...] los ayuntamientos guipuzcoanos no han decidido nada sobre tan graves cuestiones políticas, ni por cierto podrían hacerlo, sino que, en su condición de órganos representativos de sus respectivas comunidades vecinales, se han limitado pura y simplemente a proponer y pedir nuevas orientaciones y soluciones a dichas cuestiones»; J. Leguina (1977), «La potestad gubernativa de suspensión de acuerdos locales que infrinjan manifiestamente las leyes: alcance y límites», Revista de Administración Pública, 82, págs. 9-26 (pág. 18).

17 STS 2921/1987, de 9 de febrero, caso desnuclearización de Valdoviño, FJ 2º. En sentido similar, véase: STS 3994/1987, de 8 de junio, caso desnuclearización de Baracaldo, FJ $5^{\circ}$. 
Sea de ello lo que fuere, resulta pertinente subrayar que son numerosos los acuerdos municipales que no contienen petición alguna, o bien la contienen de forma tangencial o a modo de coda en uno de sus apartados. En estos casos, resulta discutible que los mismos constituyan un ejercicio del derecho de petición. Y lo mismo cabe decir de aquellas declaraciones que consisten en peticiones a otros órganos del propio municipio, como las dirigidas al alcalde o la Junta de Gobierno local ${ }^{18}$. El encaje de este tipo de declaraciones en el marco del derecho de petición resulta, en nuestra opinión, forzado y voluntarista. Y esto porque su tenor, esencialmente simbólico y declamatorio, su finalidad, fundamentalmente política, sus destinatarios, principalmente la opinión pública y la comunidad vecinal, su forma de manifestación, solemne y mediática... todo en torno a estas declaraciones indica que no tienen como objetivo principal trasladar una petición a otra Administración o poder público, sino participar activamente en el debate público. Quizá estas declaraciones puedan contener, vayan seguidas o acompañadas de una petición, pero en sí mismas consideradas constituyen una realidad claramente diferente ${ }^{19}$.

La consideración de las declaraciones institucionales como un ejercicio del derecho de petición tiene como efecto principal eximirlas de cualquier tipo de control jurídico. En efecto, si contra el vicio de pedir está la virtud de no dar, habrá que concluir que los municipios podrán pronunciarse sobre cualquier tipo de materia y solicitar la actuación de las administraciones competentes en un sentido o en otro, sin que ningún juez deba entrar a valorar si dichas peticiones resultan o no tempestivas, lo que quedará a juicio exclusivo de la Administración o poder público interpelado.

En tercer lugar, cierta jurisprudencia menor ha caracterizado algunas declaraciones simbólicas como actuaciones informales o como meros actos de trámite, deduciendo de ello que las mismas no pueden ser enjuiciadas por la jurisdicción contencioso-administrativa ${ }^{20}$.

Por ejemplo, en relación con una declaración de Gijón relativa a la campaña de boicot contra Israel, el Juzgado de lo Contencioso-Administrativo núm. 1 de dicha localidad señaló que la declaración municipal «carece de efectos jurídicos frente a los administrados, ya que no estamos ante un acto administrativo en

18 La STSJ de Asturias 1411/2018, de 28 de mayo, caso BDS en Gijón, entiende ajustada a derecho una declaración en la que el Pleno insta a los órganos de gobierno municipales a sumarse a la campaña BDS contra Israel, al estimar que la declaración es tan solo un acto de trámite que contiene una petición, sin efecto jurídico alguno.

19 La STSJ de Cataluña 10729/2018, de 22 de junio, FJ 3º, caso independencia Masnou, anula una parte del acuerdo al entender que la declaración municipal contenía, «bajo la apariencia formal de una petición, acuerdos de naturaleza instrumental y complementaria respecto del aserto principal — declaración municipal de soberanía—, y que tienen vocación aplicativa $[\ldots] »$.

20 Desde tribunas doctrinales, Díaz González (2019: 162) caracteriza ciertas declaraciones simbólicas como actuaciones informales. 
sentido técnico y estricto como declaración de voluntad o resolución que produzca efectos jurídicos en la esfera o ámbito jurídico de los administrados. El acto impugnado carece de contenido decisorio y nada decide en definitiva, puesto que en realidad solo contiene una petición dirigida a otros órganos del Ayuntamiento» ${ }^{21}$. Y el Tribunal Superior de Justicia de Asturias confirma dicho criterio, apuntando que la declaración «lo que recoge es una propuesta de acuerdo en la que se limita a instar al Gobierno municipal, de acuerdo con lo indicado en el mismo, a modo de una propuesta o petición, que participa de la naturaleza de acto de trámite sin eficacia vinculante $[\ldots] »^{22}$.

De admitir la caracterización de las declaraciones como actuaciones informales o meros actos de trámite no cualificados, el posible control jurisdiccional de las mismas se reduciría a su mínima expresión. En nuestra opinión, la citada jurisprudencia menor yerra de forma palmaria al ignorar que las declaraciones municipales son un acto formal acabado y definitivo que emite un órgano administrativo a través de un procedimiento jurídicamente reglado, con lo que difícilmente pueden ser calificadas como una actividad informal de la Administración, o como meros actos de trámite. Revestir la declaración simbólica bajo la forma de un presunto acto de trámite o una especie de autopetición a otros órganos municipales con el indisimulado fin de burlar el control judicial resulta un ardid que, a nuestro entender, no debería en ningún caso inmunizar a la declaración simbólica del pertinente escrutinio judicial.

\section{LOS EFECTOS DE LAS DECLARACIONES}

Más allá del esclarecimiento de su naturaleza, probablemente el elemento más relevante a la hora de determinar la legalidad de una declaración simbólica es la de su capacidad de afectar a la esfera de derechos o intereses de personas o colectivos. Si bien, en puridad, las declaraciones simbólicas municipales carecen de efectos jurídicos, no resulta infrecuente que las mismas contengan acuerdos de diversa índole, de entre los cuales algunos resulten idóneos para desplegar efectos jurídicos en la esfera de los administrados o en las relaciones interadministrativas.

Pues bien, un consenso ampliamente extendido entiende que las declaraciones institucionales que puedan generar efectos en el plano jurídico estarán sujetas a un control de legalidad más estricto.

En base a este motivo, por ejemplo, la jurisprudencia viene declarando inválidas las declaraciones municipales de persona non grata. Para el Tribunal Supremo, este tipo de declaraciones no consisten tan solo en manifestaciones de desagrado indiferentes para el derecho, sino que son plenamente enjuiciables toda vez que su significado estigmatizante es idóneo para incidir «en la esfera moral y, aun

21 Sentencia del Juzgado de lo Contencioso Administrativo núm. 1 de Gijón 211/2017, de 20 de noviembre, caso BDS en Gijón.

22 STSJ de Asturias 1411/2018, de 28 de mayo, FJ 2ª, caso BDS en Gijón. 
patrimonial, del destinatario que puede ver, incluso, deterioradas sus expectativas profesionales o mercantiles con el propio vecindario $»^{23}$.

Más recientemente, algunos tribunales superiores de justicia han fundamentado la invalidez de acuerdos de apoyo a la campańa BDS contra Israel en sus potenciales efectos jurídicos, para lo que no ha sido óbice el carácter pretendidamente simbólico y retórico de los mismos. Así, el TSJ de Madrid argumenta:

[...] no cabe considerar que el acuerdo carezca de eficacia jurídica alguna. Estamos ante un acto administrativo que contiene un compromiso del Ayuntamiento a no establecer convenio, contrato o acuerdo [...] con instituciones, empresas y organizaciones israelies, hasta que Israel no reconozca el derecho a la autodeterminación del pueblo palestino y acate el derecho internacional. No se queda en una mera declaración, sino que adopta unos compromisos para el futuro en orden a la suscripción de convenios y celebración de contratos, lo que determina la invalidez del acuerdo impugnado ${ }^{24}$.

En sentido opuesto, tanto la jurisprudencia como la doctrina se muestran más concesivas con las declaraciones institucionales sin incidencia en la esfera jurídica de los administrados ${ }^{25}$. A este respecto resulta ilustrativa la STS 1691/2008, de 23 de abril, caso adhesión de Llodio a Udalbiltza. A pesar de reconocer que probablemente la asociación de concejales Udalbiltza era irregular, y que resultaba discutible que el municipio en cuanto tal pudiera adherirse a la misma, el Alto Tribunal se resistió en su sentencia a declarar nulo el acuerdo, al constatar que el mismo carecía de efecto jurídico alguno. Esta es su argumentación: «[...] lo que se impugna es una actividad municipal carente de efectos prácticos directos, que esencialmente se limita a expresar una opinión política como manifestación de la voluntad concorde de los miembros de la Corporación [...]» ${ }^{26}$. En sentido similar, en el año 2018 el TSJ de las Islas Baleares declaró conforme a derecho un acuerdo del Pleno de Palma de Mallorca en el que se manifestaba su voluntad de que no se celebrasen en el municipio corridas de toros, y ello a pesar de que la normativa estatal y autonómica admitían ese tipo de espectáculos. En su sen-

23 STS 4836/1998, de 17 de julio, FJ 3º, caso persona non grata en Oleiros. En idéntico sentido, STS 1152/2004, de 23 de febrero, caso persona non grata en Garachico.

24 STSJ de Madrid 6797/2017, de 14 de junio, FJ 3º, caso BDS en Rivas Vaciamadrid. En sentido similar, véase la STSJ de las Islas Canarias 4300/2018, de 26 de septiembre, caso BDS en Gran Canaria.

25 Por ejemplo, Leguina (1977: 25) o Barata i Mir (1999: 223). Para un análisis en detalle de la jurisprudencia menor en relación con las declaraciones de boicot contra Israel, véase J. M. Alegre Ávila (2020), «Acerca del control jurisdiccional de las mociones municipales que llaman al boicot del Estado de Israel... o que declaran non grata a una persona física o jurídica», AEPDA. Disponible en: http://www.aepda.es/

26 STS 1691/2008, de 23 de abril, FJ 30 , caso adhesión de Llodio a asociación de concejales. En idéntico sentido, véase la STS 3190/1998, de 18 de mayo, FJ 1º, caso Olazagutía y gobernador civil. 
tencia, el tribunal balear avaló el acuerdo, esgrimiendo que el mismo debía «ser entendido como una declaración de intenciones o voluntad, sin efectos jurídicos, ya que incurrirían en ilegalidad manifiesta ${ }^{27}$.

No es infrecuente, como ya se ha apuntado, que una misma declaración simbólica contenga cláusulas con efectos jurídicos y cláusulas puramente declamatorias. En estos casos, una solución intermedia a la que ha recurrido reiteradamente la jurisprudencia es la de enjuiciar de forma independiente cada una de las partes del acuerdo, procediendo a declarar nulas aquellas susceptibles de producir efectos jurídicos, y admisibles las que simplemente contienen posicionamientos carentes de cualquier efectividad ulterior. Esta es la vía escogida, por ejemplo, por la STS 3994/1987, de 8 de junio, caso desnuclearización de Baracaldo. En su sentencia, en lugar de emitir un pronunciamiento global sobre el acuerdo del Pleno, el Tribunal Supremo declara nulas las cláusulas que implican ciertas prohibiciones de circulación, instalación o almacenamiento de material nuclear en el término municipal; al tiempo que entiende válidas las cláusulas sin efectos jurídicos concretos, como la que expresa la disconformidad del municipio con la instalación de misiles nucleares en territorio europeo ${ }^{28}$.

Con ser el criterio más sólido de los empleados por la jurisprudencia para enjuiciar la licitud de las declaraciones simbólicas, el criterio de la afección a la esfera de derechos e intereses legítimos de los administrados no es completamente nítido ni ha sido siempre determinante.

De un lado, no es un criterio completamente nítido, ya que en ocasiones resulta complejo dilucidar si una determinada declaración simbólica afecta a la esfera de derechos e intereses legítimos de los ciudadanos. ¿Afecta a la esfera jurídica de ciudadanos y empresas israelíes una declaración simbólica que invita al boicot contra Israel, si la misma no va seguida de la adopción de medidas más concretas? ¿Perjudica a empresas y asociaciones que promueven la tauromaquia la declaración de Palma de Mallorca como municipio antitaurino? ¿Incide en la esfera de un vecino de Vic la declaración simbólica de adhesión de su municipio al proceso soberanista catalán? Como evidencian estas cuestiones - y las divergentes respuestas que jueces y tribunales han ofrecido a las mismas-, no siempre será fácil discernir cuándo una declaración simbólica es idónea para incidir en la esfera jurídica de los administrados y cuándo no.

De otro lado, el criterio de los efectos jurídicos tampoco ha resultado determinante. En efecto, no es insólito que el Tribunal Supremo declare inválidos acuerdos carentes de cualquier efecto jurídico, cuando los mismos impliquen una invasión competencial evidente o pretendan dar carta de naturaleza a situaciones

27 STSJ Islas Baleares, 215/2018, de 22 de marzo, FJ 2º, caso Palma municipio antitaurino.

28 STS 3994/1987, de 8 de junio, FFJ 20 y 4º caso desnuclearización de Baracaldo. Curiosamente, en otros casos prácticamente idénticos — como el resuelto en la STS 2178/1986, de 30 de abril, caso desnuclearización de Hospitalet de Llobregat-, el Tribunal Supremo no hila tan fino, declarando íntegramente nula toda la declaración. 
jurídicas contrarias al ordenamiento jurídico. Es el caso de la STS 7875/1988, de 11 de noviembre, que anuló un acuerdo de hermanamiento del municipio canario de Santa Lucía con el municipio de La Güera, que el acuerdo declaraba integrado territorialmente en el seno de una pretendida República Árabe Saharaui Democrática. A pesar de que el acuerdo de hermanamiento carecía de efecto jurídico alguno en la situación jurídica de La Güera respecto de Marruecos, y no afectaba directamente a la esfera jurídica de nadie, el Tribunal Supremo entendió que el mismo, lejos de constituir una legítima manifestación política, debía ser interpretado como una «manifiesta extralimitación competencial» que menoscababa las competencias estatales e interfería en su ejercicio, por lo que procedió a declararlo nulo de pleno derecho ${ }^{29}$.

\section{LA AUTONOMÍA DE LOS MUNICIPIOS Y LOS CONCEJALES}

A la hora de determinar si una declaración simbólica se ajusta o no a la legalidad, doctrina y jurisprudencia han recurrido a diferentes interpretaciones del principio de autonomía municipal, reconocido en los arts. 137 y 140 de nuestra Carta Magna ${ }^{30}$.

Antes de presentar los aspectos en los que existen discrepancias, resulta oportuno subrayar la existencia de un amplio consenso a la hora de admitir las declaraciones simbólicas en materias que, a pesar de no ser competencia municipal, conciernen de forma innegable al círculo de los intereses locales ${ }^{31}$. En efecto, nadie duda que la autonomía local justificaría, por ejemplo, una declaración municipal sobre la construcción de una central nuclear o un embalse en el término del municipio, aunque la competencia en materia de energía nuclear esté atribuida en exclusiva al Estado.

Las divergencias interpretativas surgen en relación con declaraciones sobre materias cuya conexión con el círculo de intereses municipales es más remota, como puede ser la honorabilidad de Donald Trump o la protección de los derechos humanos en la franja de Gaza. El juicio de legalidad sobre estas declaraciones dependerá del concepto de autonomía local que se admita. Veamos las dos posiciones al respecto.

Una primera posición sostiene un concepto de autonomía local acotado, circunscrito al ámbito de intereses y competencias municipales establecido por la

29 STS 7875/1988, de 11 de noviembre, FJ 1º, caso hermanamiento de Santa Lucía con municipio saharaui.

30 La naturaleza y extensión de la autonomía local ha sido objeto de numerosos pronunciamientos del Tribunal Constitucional, entre los que destacan las tempranas SSTC 4/1981, de 2 de febrero, y 32/1981, de 28 de julio.

31 En este sentido, véase, por todos, Barata i Mir (1999: 104). 
Constitución y la legislación estatal y autonómica ${ }^{32}$. Partiendo de esta concepción restringida de la autonomía local, se concluye que solo resultan admisibles aquellas declaraciones institucionales que recaigan sobre aspectos relativos al círculo de intereses municipales ${ }^{33}$.

Diferentes pronunciamientos refrendan esta interpretación estricta del principio de autonomía local. Por ejemplo, la STS 7875/1988, de 11 de noviembre, caso hermanamiento de Santa Lucía con municipio saharaui, afirma categóricamente que «la autonomía local (arts. 137 y 147 de la Constitución Española) ha de contenerse en los límites de la gestión de sus respectivos intereses", por lo que procede a declarar la nulidad de pleno derecho del acuerdo de hermanamiento por invadir el espacio competencial del Estado en materia de política exterior ${ }^{34}$. Más recientemente, la STS 2088/2019, de 26 de junio, caso independencia Caldes de Montbui, niega rotundamente que la declaración municipal de adhesión al proceso soberanista catalán fuera un ejercicio legítimo de autonomía municipal - como pretendía la representación procesal de la corporación local—, ya que el objeto de la declaración excedía el marco competencial del municipio ${ }^{35}$. De esta jurisprudencia se deduce que la autonomía local ha de ejercerse dentro de los lindes delimitados por los intereses naturales del municipio, y no sobre cuestiones situadas de forma evidente más allá de los mismos.

En esta línea argumental, las sentencias que declaran nulos acuerdos sobre materias ajenas al círculo de intereses municipales excluyen que dichos acuerdos se limiten a expresar la opinión particular de los concejales que las suscriben, y subrayan que estos acuerdos revisten una naturaleza oficial o institucional. De forma a nuestro parecer acertada, esta jurisprudencia subraya que las declaraciones simbólicas son actos imputables a la propia corporación, y no a sus miembros individual o colectivamente considerados ${ }^{36}$. Por ello, se rechaza que dichas decla-

32 Desde estas concepciones más restrictivas de la autonomía local se pone el acento en la diferencia sustancial existente entre la autonomía local y la del Estado y las comunidades autónomas, donde existen poderes legislativos y donde el Ejecutivo reviste una independencia nítida respecto de la Administración.

33 En este sentido, J. L. Martínez López-Muñiz (2002), «Actos de gobierno y Administración Local», en J. Climent Barberá y J. M. Baño León (coords.), Nuevas perspectivas del régimen local: estudios en homenaje al profesor José María Boquera Oliver (págs. 639-683), Valencia: Tirant lo Blanch (pág. 680).

34 STS 7875/1988, de 11 de noviembre, FJ 2º, caso hermanamiento de Santa Lucía con municipio saharaui.

35 STS 2088/2019, de 26 de junio, FFJJ 6º y 7o , caso independencia Caldes de Montbui. El Tribunal Supremo ha reiterado la argumentación contenida en esta sentencia en las SSTS 2218/2019, de 28 de junio; 2211/2019, de 1 de julio; y 2213/2019, de 1 de julio, todas ellas sobre acuerdos de adhesión al procedimiento soberanista catalán.

36 Desde tribunas doctrinales apoya esta posición J. M. Bermejo Latre (2008), «La Administración y el derecho al honor", Revista de Administración Pública, 175, págs. 375-398 (pág. 391). 
raciones queden amparadas en la libertad de expresión o en los derechos asociados a la representación política de los concejales que con su voto respaldan la declaración, reconocidos en los arts. 20 y 23 de la Constitución. Así lo expone, por ejemplo, la STS 4836/1998, de 17 de julio, caso persona non grata en Oleiros:

[...] una declaración que no procede de alguno de los miembros de la Corporación, sino que constituye la manifestación de un juicio que pretende atribuirse a la propia Corporación en cuanto tal, como decisión municipal, ha de encontrar una habilitación legal, que, en el presente caso, no se encuentra ni en las competencias municipales nominadas del art. 25 de la Ley Reguladora de las Bases de Régimen Local [...] ni en la propia cláusula de la autonomía municipal al no aparecer concernido el interés municipal o las necesidades de la comunidad vecinal ${ }^{37}$.

Frente a esta posición estricta, existe una segunda interpretación más amplia de la autonomía reconocida constitucionalmente a los municipios, que justifica la adopción de declaraciones sobre cuestiones de interés general, aunque no estén directamente conectadas con los intereses vecinales ${ }^{38}$.

Esta posición concibe a los órganos municipales representativos como órganos políticos, legítimamente habilitados para manifestar sus posicionamientos o preferencias en las más diversas cuestiones mediante actuaciones de carácter político, exentas de los rigorismos propios del ejercicio de las potestades administrativas $^{39}$. Desde esta perspectiva, se entiende que vedar a los municipios la posibilidad de pronunciarse sobre cuestiones de interés general — por muy distantes que resulten de los intereses propiamente municipales - equivaldría a cercenar desproporcionadamente su autonomía, o, como apunta Díaz González, a petrificar injustificadamente sus posibilidades de participación en el debate público ${ }^{40}$. Como administración territorial que es, el municipio tendría para estos autores una universalidad o generalidad de fines; es decir, su círculo de intereses sería ilimitado, coincidente con el del Estado y la comunidad autónoma. Cuestión diferente sería la de quién está llamado a ejercer competencias respecto de cada materia en concreto.

En esta línea argumental se sitúa el Tribunal Supremo cuando declara conforme a derecho un punto del acuerdo de desnuclearización de Baracaldo, en el que el municipio se limitaba a manifestar su oposición a la instalación y mante-

37 STS 4836/1998, de 17 de julio, FJ 4º, caso persona non grata en Oleiros. A pesar de rechazar el recurso contra el acuerdo municipal, contiene una argumentación similar la STC 185/1989, de 13 de noviembre, FJ 4º, caso persona non grata en Priego.

Esta es la posición defendida, por ejemplo, por A. Embid Irujo (1993), «La actividad de gobierno de las entidades locales y su control jurisdiccional. Nuevas reflexiones sobre el control de la actividad de gobierno de los poderes públicos», Revista de Estudios de la Administración Local y Autonómica, 258, págs. 251-288 (pág. 279).

40 Díaz González (2019: 160-161). 
nimiento de misiles nucleares en territorio europeo. Respecto de dicho punto, afirma el Alto Tribunal:

[...] aunque no deja de ser una extralimitación respecto de las competencias establecidas para las Corporaciones Municipales [...] sólo constituye una postura ideológica respecto de tal cuestión, en realidad atinente tan sólo a los componentes de la Corporación que la han apoyado, que, aunque discutible por su carácter subjetivo, es respetable, en cuanto manifestación de su parecer frente a quien puede hacer valer los derechos de España ante las potencias extranjeras interesadas ${ }^{41}$.

En sentencias similares, el Tribunal Supremo justifica las declaraciones mediante una apelación a la libertad de expresión de los concejales, engarzando las declaraciones municipales con los arts. 20 y 23 de la Constitución. Esto se hace atribuyendo el acuerdo — de forma harto discutible - exclusivamente a los concejales que lo suscriben, y no propiamente a la corporación en cuanto tal. Así, por ejemplo, afirma la STS 1691/2008, de 23 de abril, caso adhesión de Llodio a asociación de concejales:

[...] nos encontramos, por tanto, en un supuesto de expresión de una opinión en el ejercicio de cargo público cuya libertad garantiza la propia Constitución (arts. 20 y 23), resultando que en lo que pudiera entenderse parte dispositiva del acuerdo el Ayuntamiento no ejercita una potestad administrativa que no tenga atribuida, ni tan siquiera trata de ejercitar potestad administrativa alguna, sino que se limita a manifestar un deseo [...] lo que determina que no pueda estimarse la pretensión anulatoria ejercitada por la demanda ${ }^{42}$.

Concluimos este apartado señalando que el debate jurisprudencial y doctrinal en torno al alcance de la autonomía local es, sin duda alguna, la causa principal de la confusión reinante en relación con la validez de las declaraciones simbólicas. Si se parte de la premisa de que los municipios carecen de autonomía política plena, se concluirá que es preciso acotar las declaraciones simbólicas a aquellos asuntos que les conciernen de forma más o menos directa. Por el contrario, si se admite que los municipios son entidades con una autonomía política plena, análoga de la que se predica de las comunidades autónomas y el Estado, se

41 STS 3994/1987, de 8 de junio, FJ 5º, caso desnuclearización de Baracaldo.

42 STS 1691/2008, de 23 de abril, FJ 2º, caso adhesión de Llodio a asociación de concejales. En idéntico sentido, STS 3190/1998, de 18 de mayo, FJ 1º, caso Olazagutía y gobernador civil. La Sala de lo Penal del TS ha asumido esta posición en diferentes resoluciones, como STS 10575/1994, de 15 de marzo, FJ 5º, caso persona non grata en Grado, que afirma que la declaración se trata, «en suma, de una simple apreciación subjetiva de determinados miembros de la corporación municipal de Grado respecto de la persona que a la sazón ocupaba el cargo de Juez de Instrucción en dicha localidad». 
impone la conclusión de que están perfectamente legitimadas para pronunciarse simbólicamente sobre cualquier asunto de interés público.

\section{LA CUESTIÓN COMPETENCIAL}

Como se ha señalado, las declaraciones simbólicas controvertidas lo son, principalmente, por versar sobre cuestiones ajenas al círculo de intereses municipales, lo que comporta a su vez la ausencia de atribución competencial a favor de los municipios respecto de las mismas. ¿¿Determina de forma inevitable esta falta de competencia la ilegalidad de las declaraciones simbólicas?

La posición jurisprudencial mayoritaria — siempre, recordémoslo, tomando como referencia el pequeño número de declaraciones que son impugnadas judicialmente- entiende que $\mathrm{si}^{43}$. Esta línea jurisprudencial interpreta de forma positiva el principio de vinculación de la Administración a la ley, por lo que restringe el legítimo ámbito de actuación de los municipios a aquellas materias que tienen expresamente atribuidas por el legislador, conforme al art. 25 LBRL. Con estas premisas, se excluye de plano la admisibilidad de aquellas actuaciones - incluidas las declaraciones simbólicas - que rebasen dicho círculo competencial.

Entre las muchas sentencias que podrían traerse a colación, resulta paradigmática la STS 595/1988, de 3 de febrero, caso desnuclearización de Leganés, cuyo Fundamento Jurídico $1^{\circ}$ reza: la declaración municipal,

[...] en cuanto ejercicio de una potestad para el cumplimiento de los fines que le están encomendados, sólo puede dictarse en función de las atribuciones concedidas por las leyes, y como el acto impugnado afecta a potestades exclusivas del Estado recogidas en el art. 149 de la Constitución [...] su adopción representa una intromisión en las competencias que al Estado atribuye la Constitución, que no puede encontrar amparo en el principio de autonomía municipal consagrado en el art. 137 de la Constitución.

Más recientemente, la STS 2088/2019, de 26 de junio, caso independencia Caldes de Montbui, contiene idéntica argumentación, subrayando que la posibilidad de adoptar acuerdos en el Pleno municipal no constituye «una cláusula que permita al ente local efectuar en forma innominada declaraciones totalmente desvinculadas del ámbito de las competencias municipales» ${ }^{44}$.

43 La propia LBRL contiene un artículo específico sobre las actuaciones municipales en materia de competencia ajena, el 66, cuyo tenor literal dice: «[...] los actos o acuerdos de las Entidades locales que menoscaben competencias del Estado o de las Comunidades Autónomas, interfieran su ejercicio o excedan de la competencia de dichas Entidades, podrán ser impugnados por cualquiera de los procedimientos previstos en el artículo anterior». Cabría plantearse, en cualquier caso, si una declaración simbólica es idónea para "menoscabar» una competencia ajena o «interferir su ejercicio».

STS 2088/2019, de 26 de junio, FJ 7º, caso independencia Caldes de Montbui. 
Desde tribunas doctrinales también se ha defendido esta interpretación estricta del criterio competencial. Martínez-López Muñiz, por ejemplo, sostiene que si las declaraciones municipales «no pueden encontrar un anclaje suficiente al menos en la defensa de los intereses locales correspondientes, la incompetencia para su adopción podría justificar perfectamente una sentencia anulatoria en el contencioso, en recursos promovidos por miembros de la correspondiente Corporación que votaran en contra o incluso por vecinos disconformes con ellas» ${ }^{45}$.

Esta interpretación rigurosa de la vinculación positiva de la Administración local al principio de legalidad — que excluiría la legalidad de las declaraciones simbólicas sobre materias allende las competencias municipales- ha sido discutida con diferentes razonamientos.

En primer lugar, se ha sostenido que los acuerdos simbólicos no suponen invasión competencial alguna, toda vez que no despliegan efectos jurídicos susceptibles de perturbar el ejercicio de la competencia por parte de su legítimo titular ${ }^{46}$. En segundo lugar, se ha subrayado que aprobar una declaración de este estilo implica precisamente el reconocimiento de la propia incompetencia, lo excluye de suyo una extralimitación en el ejercicio de unas competencias de las que se reconoce carecer ${ }^{47}$. Otra línea argumental defiende una interpretación negativa del principio de legalidad, más acorde con la idea de Estado social, que permitiría a las Administraciones actuar o pronunciarse sobre materias de interés general siempre y cuando no infrinjan el ordenamiento jurídico ${ }^{48}$. En cuarto lugar, se ha apelado a la tradicional anuencia con la actividad declamatoria municipal, que ha sido habitualmente transigida - por inofensiva - por las propias administraciones cuyas competencias se pretende salvaguardar ${ }^{49}$. Finalmente, desde concepciones amplias de la autonomía municipal, también se afirma que los municipios y sus representantes democráticos tienen legitimidad para pronunciarse sobre cuestiones de todo tipo, siempre que las mismas tengan o puedan tener repercusión en algún interés público ${ }^{50}$.

Como ejemplo de esta interpretación laxa del criterio competencial, valga traer de nuevo a colación la argumentación contenida en la STS 3994/1987, de 8 de junio, caso desnuclearización de Baracaldo, que admite la legalidad de partes

45 Martínez López-Muñiz (2002: 680).

46 Garrido Cuenca (1998: 596), así como STS 3994/1987, de 8 de junio, caso desnuclearización de Baracaldo.

47 STS 2921/1987, de 9 de febrero, caso desnuclearización de Valdoviño. En sentido similar, Barata i Mir (1999: 102).

48 Díaz González (2019: 160 y ss).

49 Díaz González (2019: 161).

50 Así lo sostiene, por ejemplo, Barata i Mir (1999: 99). 
del acuerdo municipal al tiempo que reconoce que el mismo constituye una innegable extralimitación competencial ${ }^{51}$.

\section{EL CONTENIDO DE LA DECLARACIÓN}

Como es natural, un último elemento a tomar en consideración a fin de determinar si una declaración simbólica es o no legal es el de su contenido.

En este sentido, la jurisprudencia no ha dudado en declarar la invalidez de ciertas declaraciones cuyo contenido era dudosamente compatible con el orden constitucional.

Así, diferentes sentencias han revocado acuerdos por entenderlos lesivos de derechos fundamentales ${ }^{52}$. Por ejemplo, en fechas recientes abundante jurisprudencia menor ha declarado nulos de pleno derecho acuerdos de boicot contra Israel, por considerarlos contrarios al principio de igualdad y al derecho a la no discriminación (arts. $9.2^{\circ}$ y $\left.14 \mathrm{CE}\right)^{53}$. Similar fundamento ha justificado también la nulidad de las declaraciones de persona non grata, consideradas idóneas para vulnerar derechos e intereses de los afectados, como el derecho a la igualdad, a la libertad ideológica o al honor ${ }^{54}$.

Junto con ello, también se han declarado nulos acuerdos declamatorios por considerarse gravemente lesivos contra principios o intereses de rango constitucional, circunstancia que incluso justifica la suspensión cautelar del acuerdo por parte del delegado de Gobierno, conforme al art. 67 LBRL. Este es el motivo que late en la STS 2088/2019, de 26 de junio, caso independencia Caldes de Montbui, en la que el Tribunal Supremo declara nula la declaración municipal por considerarla contraria al orden constitucional, a la lealtad institucional y al

51 STS 3994/1987, de 8 de junio, caso desnuclearización de Baracaldo. Y también, STSJ Islas Baleares, 215/2018, de 22 de marzo, caso Palma municipio antitaurino.

52 A este respecto, conviene recordar que el art. 2.1.a LJCA justifica la revisión judicial de cualquier tipo de acto cuando el mismo pueda conculcar un derecho fundamental.

53 Véase STSJ de Asturias 2202/2018, de 25 de junio, FJ 2º, caso BDS en Castrillón; o STSJ de Madrid 6797/2017, de 14 de junio, FJ 3º, caso BDS en Rivas Vaciamadrid.

54 Una línea jurisprudencial reiterada - y sorprendente- niega que estas declaraciones vulneren el derecho al honor. Así, por ejemplo, las STC 185/1989, de 13 de noviembre, caso persona non grata en Priego, y la STS 4836/1998, de 17 de julio, caso persona non grata en Oleiros. Personalmente, consideramos innegable que dichas declaraciones vulneran el derecho al honor, como ha defendido entre otros G. Doménech Pascual (2004), «Las declaraciones administrativas de persona non grata. Reflexiones sobre la actividad no jurídica, verbi gratia, informativa, de la Administración", Revista General de Derecho Administrativo, 7, págs. 1-25 (págs. 4-5). Con todo, también existen pronunciamientos sobre acuerdos municipales que reconocen la vulneración del derecho al honor, como la STS, Sala de lo Civil, 2219/2009, de 29 de abril, caso reprobación kiosquero por Colmenar de Oreja. 
principio de objetividad que debe presidir la actividad de las Administraciones públicas $^{55}$.

Sin ánimo de abordar toda la casuística que podría darse en relación con declaraciones de contenido contrario a la Constitución, empresa que sería inabarcable, cabe plantear aquí la licitud de las declaraciones de un municipio como espacio libre de desahucios, declaraciones que han sido muy frecuentes en la última década ${ }^{56}$. Dejando a un lado un sinfín de matices que podrían hacerse, este tipo de acuerdos, de un modo o de otro, expresan la voluntad política de exceptuar en el término municipal la aplicación de normas con rango de ley que protegen el derecho de propiedad, lo que supone una clara contravención del principio de legalidad consagrado en el art. 103 CE.

Sea de ello lo que fuere, es preciso convenir que no toda declaración de contenido no alineado con la Constitución —o con la legalidad vigente- resulta contraria a derecho, ya que no es la nuestra una democracia militante que blinde sus elementos nucleares frente a cualquier discrepancia o intento de reforma ${ }^{57}$.

A título ejemplificativo, valga recordar los ya mencionados acuerdos de ciertos municipios guipuzcoanos del año 1976, que, entre otros extremos, solicitaban al rey la aprobación de un Estatuto de Autonomía para el País Vasco. Dichos acuerdos, suspendidos por el gobernador civil en base a su pretendida inconstitucionalidad, fueron avalados posteriormente en sede judicial, al entenderse que el hecho de solicitar una modificación del statu quo de esa región de España no implicaba vulneración alguna del orden constitucional ${ }^{58}$.

De este modo, es preciso concluir que la forma en que se haga la declaración simbólica de contenido inconstitucional o ilegal será decisiva a fin de determinar su admisibilidad. Si la declaración se limita a promover la válida revisión del ordenamiento constitucional vigente, resultará plenamente legal; si, por el contrario, aboga expresamente por cauces de reforma no previstos en el sistema — como hacían, verbigracia, las ya mencionadas declaraciones de adhesión al proceso soberanista catalán—, resultará inválida ${ }^{59}$.

55 STS 2088/2019, de 26 de junio, FJ 8º, caso independencia Caldes de Montbui.

56 Entre los municipios que han aprobado acuerdos de este tipo están Granada, San Sebastián, San Pedro del Pinatar, Ordizia, Rincón de la Victoria...

57 Entre una amplia jurisprudencia que podría citarse en este sentido, destacamos la STC $42 / 2014$, de 25 de marzo, que recuerda que las meras manifestaciones institucionales que se opongan a lo establecido en la Constitución no deben en todo caso dar lugar a pronunciamientos del Tribunal Constitucional. Desde un punto de vista doctrinal, resulta de interés A. Catalá i Bas (2012), "El modelo de democracia militante del Tribunal Europeo de Derechos Humanos", en Constitución y Democracia: ayer y hoy. Libro homenaje a Antonio Torres del Moral, vol. 2 (págs. 3243-3258), Madrid: Universitas.

58 Así lo entiende también Leguina (1977: 22).

59 Sobre el particular, y en relación con la declaración de adhesión de Caldes de Montbui al proceso soberanista catalán, resulta de interés Díaz González (2019: 162 y ss.). 


\section{APORTACIONES AL DEBATE: LA NEUTRALIDAD IDEOLÓGICA DE LA ADMINISTRACIÓN Y LA AUSENCIA DE MANDATO REPRESENTATIVO}

Para concluir nuestro estudio, nos gustaría presentar dos objeciones a las declaraciones municipales simbólicas, que hasta el momento no han sido objeto de una exploración doctrinal y jurisprudencial detenida, y que en nuestra opinión podrían enriquecer el debate en torno a la admisibilidad de las mismas.

\section{LA NEUTRALIDAD IDEOLÓGICA DE LA ADMINISTRACIÓN Y EL RESPETO AL PLURALISMO}

Como se ha tenido ocasión de señalar, las declaraciones simbólicas a menudo versan sobre cuestiones de actualidad que son objeto de atención y discusión en la opinión pública. Como es natural, nada obsta a que los concejales debatan en el Pleno municipal esas cuestiones, o a que se pronuncien individual o colectivamente sobre las mismas ${ }^{60}$. Ahora bien, que lo hagan mediante una declaración institucional del Pleno genera mayores dudas.

De un lado, cabe plantearse si estas declaraciones son conformes con el principio de neutralidad ideológica del Estado, que se deriva del art. $16 \mathrm{CE}^{61}$. Conforme a este principio, las Administraciones públicas no son competentes "para prever e imponer una concepción sistemática, ideología o pensamiento global acerca del hombre, del mundo y de la vida ${ }^{62}$. Si bien es cierto que este principio ha sido desarrollado hasta la fecha en el contexto de la libertad religiosa de los ciudadanos, nada impide extender sus efectos a otras áreas de la libertad de pensamiento, particularmente si se detecta un intento de ciertas Administraciones de elevar a categoría de "pensamiento único» o «verdad oficial» posiciones

60 Estas expresiones privadas sobre materias de interés público constituyen un ejercicio legítimo de la libertad de expresión, que los representantes democráticamente elegidos tienen reconocida de forma reforzada conforme a una asentada tradición jurisprudencial. Entre muchas, cabe citar a este respecto la STC 9/1990, de 18 de enero.

61 Nótese que no abordamos aquí el principio de neutralidad desde el prisma del art. 103 $\mathrm{CE}$, en relación con la objetividad que ha de regir el quehacer de la Administración, sino desde el art. 16, relativo a la libertad ideológica. Para un análisis del principio de neutralidad de la Administración en el marco del art. $103 \mathrm{CE}$, resultan de interés las SSTC 77/1985, de 27 de junio; 190/2001, de 1 de octubre; y 80/2002, de 8 de abril; y también: F. M. García Costa (2011), «Delimitación conceptual del principio de objetividad: objetividad, neutralidad e imparcialidad", Revista Documentación Administrativa, 289, págs. 21-42.

62 J. M. Beneyto Pérez (1996), "Art. 16. La libertad ideológica y religiosa», en O. Alzaga (dir.), Comentarios a la Constitución, tomo II (págs. 303-338), Madrid: Edersa (pág. 314). 
políticas que, por muy razonables y mayoritarias que sean, resultan discutidas y discutibles, como pueden ser aquellas en relación con cuál es la protección debida al toro de lidia, si Cataluña debe constituirse como un Estado independiente, o si nos hallamos en una situación de emergencia climática. La imposición de esta exigencia de neutralidad a la Administración en relación con determinadas formas de comunicación pública no es ajena a nuestro ordenamiento jurídico que, por ejemplo, distingue en período electoral las campañas políticas institucionales de las llevadas a cabo por partidos políticos ${ }^{63}$; o que requiere una cierta neutralidad política a las comunicaciones provenientes o gestionadas por las Administraciones, a fin de evitar el uso de los canales de comunicación oficiales como tribunas al servicio de la propaganda partidista ${ }^{64}$.

En íntima conexión con lo anterior, conviene no perder de vista la ventaja con la que cuentan las instituciones públicas para hacer oír su voz en el debate público respecto de otros agentes políticos. Un abuso de esta posición de privilegio podría ocasionar un perjuicio para el pluralismo político - reconocido en el art. $1 \mathrm{CE}$ como un valor superior del ordenamiento- y una amenaza para el mantenimiento de una opinión pública libre — protegida en el art. 20 $\mathrm{CE}$, en el contexto de los derechos comunicativos ${ }^{65}$ - . Lo advierte con acierto Villaverde, criticando la creciente tendencia de las instituciones públicas a participar en los debates de actualidad: «[...] la irrupción de estas opiniones institucionales puede alterar gravemente la apertura y libertad del debate público de ideas porque lo que dice una institución pública puede tener efectos jurídicos y viene acompańada de una auctoritas que puede desequilibrar el igual peso que deben tener en el proceso de comunicación pública toda opinión que circula en él» ${ }^{66}$. Las Administraciones públicas, no se olvide, no disfrutan de libertad de expresión, con lo que deberían abstenerse de manifestar sus opiniones de forma institucional en los debates públicos que se mantienen en el seno de la sociedad,

63 Así el art. 50 de la Ley Orgánica 5/1985, de 19 de junio, del Régimen Electoral General.

64 Sobre el particular, A. Salerno (2000), «La "comunicación institucional” o "comunicación imagen”", en J. Tornos Mas y A. Galán Galán (coords.), Comunicación pública: la información administrativa al ciudadano (págs. 173-211), Madrid-Barcelona: Marcial Pons (pág. 186).

65 Peralta Martínez subraya la conexión entre neutralidad ideológica y pluralismo político en los siguientes términos: «el pluralismo político es uno de los cuatro valores-guía del régimen constitucional español (art. 1.1 CE), de manera que los poderes públicos deberán actuar en este sentido desde la más exquisita neutralidad abandonando toda pretensión tendente a imponer oficialmente una determinada ideología política». R. Peralta Martínez (2012), «Libertad ideológica y libertad de expresión como garantías institucionales», Anuario Iberoamericano de Justicia Constitucional, 16, págs. 251-283 (pág. 254).

66 Villaverde Menéndez (2018). 
salvo que circunstancias de interés general recomienden su intervención, lo que resultará excepcional ${ }^{67}$.

Como es natural, tanto los gobiernos como el colegio de representantes de los vecinos de un municipio tienen sus propias inclinaciones políticas, y resulta tan legítimo como deseable que se esfuercen en plasmarlas en políticas y decisiones concretas. Ahora bien, esta legitimidad no es una patente de corso para pronunciarse de cualquier manera sobre cualquier tipo de cuestión, con la indisimulada intención de condicionar la opinión de la ciudadanía sobre los más variados asuntos. Formas existen para que los agentes políticos mayoritarios en un municipio impriman su orientación y su sensibilidad en la vida cotidiana y en las rutinas administrativas del ente local, de acuerdo con el mandato representativo que han recibido del cuerpo electoral. Dicha orientación política podrá plasmarse de muy diversas formas, tanto a través del ejercicio reglado de las potestades públicas — reglamentaria, de fomento, de servicio público, sancionadora- como mediante el recurso a actividades informales lícitas en derecho - discursos del alcalde, convocatorias de minutos de silencio...-. Ahora bien, recurrir al expediente de las declaraciones simbólicas del Pleno para promover una cierta agenda política o dar una pátina de "oficialidad» a determinadas posiciones partidistas - por mayoritarias que estas sean en el municipio- difícilmente se compadece con las exigencias derivadas de los principios de neutralidad ideológica, pluralismo y legalidad que han de regir la actuación de la Administración, por lo que podría considerarse una desviación de poder. Y esto porque el abuso de la actividad declamatoria supone la utilización de una institución pública, el Pleno de un Ayuntamiento, para una finalidad que no le es propia, cual es la de participar en el debate público mediante la publicitación de opiniones institucionales ${ }^{68}$.

Es preciso convenir que la mayoría de las declaraciones simbólicas a las que venimos refiriéndonos suponen la escenificación de un discurso «que no puede entenderse necesaria para llevar a cabo una política de gobierno, sino que está destinada simplemente a provocar una adhesión emocional a las opciones ideológicas» de las mayorías que dominan el Pleno ${ }^{69}$. Estamos, pues, ante un discurso en el que «la transparencia se confunde con la publicidad o la propaganda, y en el que se utiliza el propio prestigio que tiene lo público frente a los ciudadanos para defenestrar determinadas opciones privadas dentro de la comunidad política», al tiempo que se ensalzan otras ${ }^{70}$.

67 Sobre esta cuestión, véase Salerno (2000: 179). Para un análisis certero de las situaciones en las que la intervención de las administraciones será recomendable o necesaria, véase F. Velasco Caballero (1998), La información administrativa al público, Madrid: Montecorvo.

V. J. Vázquez Alonso (2017), «La neutralidad del Estado y el problema del Government Speech", Revista de Estudios Políticos, 177, págs. 13-55 (pág. 49).

Ibid. 
Hasta el momento, el Tribunal Supremo no ha abordado específicamente la cuestión de la neutralidad de las Administraciones locales en el contexto de procedimientos sobre declaraciones simbólicas. Sin embargo, sí existen pronunciamientos en la línea que aquí apuntamos respecto de acuerdos adoptados por otro tipo de Administraciones. En concreto, resulta de interés la STS 8574/1992, de 20 de noviembre, que justificó la anulación de un acuerdo de la Universitat de València que denominaba catalán, en lugar de valenciano, a la lengua cooficial de la Comunitat Valenciana. Tras constatar que el fondo del asunto no era filológico ni académico, sino exclusivamente político, y que el ordenamiento jurídico calificaba dicha lengua como valenciano, el Tribunal Supremo concluyó que la anulación del acuerdo no vulneraba la autonomía universitaria, toda vez que entre «las facultades que comporta esa autonomía, y que son muchas, no está la de, cual si de un partido político se tratara (art. 6. de la Constitución), la Universidad participe como tal institución en las contiendas políticas ${ }^{71}$.

Pues bien, lo mismo cabría decir en nuestra opinión respecto de los plenos municipales: no es su finalidad participar institucionalmente en las contiendas políticas a través de declaraciones simbólicas relativas a cuestiones ajenas a su círculo de intereses, como si de partidos políticos se tratase.

Recientemente, la STS 2088/2019, de 26 de junio, caso independencia Caldes de Montbui, suscribe de forma tangencial esta idea, cuando señala en su Fundamento Jurídico $8^{\circ}$ que «una Administración Pública no se puede manifestar en una materia de la trascendencia de la que aborda el acuerdo recurrido asumiendo una posición de parte e identificando con ella a la Corporación misma [...]».

Somos conscientes de que este argumento relativo a la neutralidad y el pluralismo no es inmune a críticas y matizaciones. En primer lugar, podría subrayarse que los municipios gozan de una legitimidad política igual o mayor que cualquier partido político, de forma que tienen perfecto derecho a participar en el debate público a través de sus órganos de representación. En segundo lugar, habrá quien entienda que la aprobación de declaraciones simbólicas, lejos de perjudicar el debate público y debilitar el pluralismo, produce exactamente el efecto contrario, al poner en circulación opiniones sobre temas de actualidad que suscitan adhesión o rechazo por parte de la ciudadanía, y que invitan a una profundización en el debate. Finalmente, también podría discutirse la posición de privilegio de la Administración pública en la arena mediática, esgrimiendo la gran capacidad de comunicación de la que goza cualquier ciudadano en el descentralizado, horizontal y a menudo cacofónico concierto de las redes sociales de Internet, entorno en el que a día de hoy se canaliza en gran medida el debate político.

71 STS 8574/1992, de 20 de noviembre, FJ 10º, caso valenciano o catalán. Acerca de la autonomía universitaria, resulta de interés: R. Marzal (2016), «¿Hay actos políticos en la Universidad?», en A. Arias et al. (coords.), Usos y abusos del Derecho Universitario. Homenaje a Juan Manuel del Valle (págs. 151-156), Cizur Menor: Thomson Reuters-Aranzadi. 


\section{LA AUSENCIA DE MANDATO REPRESENTATIVO}

La segunda objeción que nos gustaría plantear a las declaraciones simbólicas que se ocupan de cuestiones sin conexión con los intereses municipales consiste en la falta de representatividad de los concejales en relación con el objeto de las mismas.

Como se ha subrayado, una de las razones que se esgrimen para justificar las declaraciones institucionales es la de sostener que los concejales han sido elegidos democráticamente por los vecinos del municipio, lo que les otorga un mandato representativo y les inviste de legitimidad para expresar públicamente la opinión de la corporación local sobre un determinado asunto.

No obstante, el argumento presenta a nuestro entender una fisura fundamental: los representantes municipales son elegidos para representar a los vecinos en aquellas cuestiones que son de interés y competencia municipal, no para hacerlo respecto de otras cuestiones que exceden dicho ámbito material. Respecto de esas otras materias, los vecinos tienen otros representantes —autonómicos, estatales, europeos-, que cuentan con otro mandato representativo y con plena legitimidad democrática.

En efecto, la pretensión de que los concejales municipales ostentan una suerte de legitimidad universal para pronunciarse en nombre de los vecinos respecto de cualquier asunto - sea o no de interés municipal - constituye una interpretación abusiva del mandato representativo que les ha sido otorgado, extendiendo su alcance más allá de lo razonable. Dicha pretensión ignora la evidencia de que muchos vecinos se decantan por diferentes opciones políticas en las elecciones locales, autonómicas, estatales y europeas, lo que debe llevar a excluir que los representantes municipales sean los legítimos portavoces de los vecinos en todos y cada uno de los debates públicos. Por consiguiente, y aunque pueda resultar una afirmación tajante, es preciso concluir que, en rigor, fuera de las materias de interés municipal, los concejales no tienen ningún tipo de legitimidad para hablar en nombre de los vecinos. Con su voto en las elecciones municipales, el vecino elige a una serie de personas para que le representen en las cuestiones que conciernen a su municipio; ahora bien, lo que no hace es entregarles un cheque en blanco para que hablen en su nombre sobre cualquier asunto, particularmente si este excede las cuestiones de interés local. Y ello porque, para materias de interés supramunicipal, el vecino cuenta con otros representantes legítimamente elegidos, que no tienen por qué compartir las posiciones defendidas por los grupos políticos con mayoría a nivel municipal.

Como señala con acierto Martínez López-Muñiz, «la utilización de una institución pública con competencias determinadas — aunque alguna se defina con alguna generalidad - para fines que no le son propios, para los que no ha sido establecida, para los que no puede utilizarse su nombre, su autoridad ni el respaldo implícito de sus ciudadanos, para los que, en fin, los titulares de sus órganos 
de gobierno no han podido ser elegidos», ni es conforme a derecho ni se debe admitir $^{72}$.

Descendiendo a un ejemplo concreto, y dicho en román paladino, un concejal no es nadie para hablar en nombre de sus electores sobre Donald Trump o sobre la sentencia de "La Manada», cuestiones que ni son objeto de interés municipal directo ni se incluyen en los programas electorales de las candidaturas al consistorio. Pretender que dicho concejal tiene un mandato representativo para pronunciarse sobre esas cuestiones es, sencillamente, falso. Por consiguiente, que el Pleno municipal adopte declaraciones en base a ese pretendido mandato constituye una suplantación ilegítima de la voluntad de los vecinos, una extralimitación en el ejercicio de sus funciones y una desviación de poder, por muy buenas intenciones que se tenga y muy justas que sean las causas con las que la declaración institucional se compromete.

El presente argumento, con parecernos sólido y convincente, también admite objeciones de peso. En primer lugar, se le puede oponer la evidencia de que la representatividad de los cargos electos no es una realidad compartimentalizada en diferentes niveles territoriales estancos y desconectados entre sí. Una cosa es reconocer que los electores pueden votar en clave municipal, autonómica, estatal o europea a opciones políticas diferentes, y otra bien distinta es pretender que entre dichas esferas no exista ningún tipo de interconexión, porque es evidente que esta existe. Esta interconexión es la que propicia, de forma pacíficamente admitida, que los representantes estatales opinen sobre cuestiones de interés local y autonómico, que los eurodiputados lo hagan sobre cuestiones estatales o que los diputados autonómicos se pronuncien sobre asuntos de carácter comunitario. ¿Por qué razón debe negarse a los representantes locales lo que se permite a todos los demás? Una segunda objeción apunta a la existencia de vías democráticas efectivas — básicamente, las siguientes elecciones - para que sean los vecinos y no los jueces quienes castiguen los excesos declamatorios de sus representantes, cuando entiendan que los mismos realizan declaraciones simbólicas discordantes con el sentir vecinal. Finalmente, puede argumentarse que la ciudadanía sabe interpretar en sus justos términos el valor de las declaraciones simbólicas, por lo que las mismas son mayoritariamente entendidas como lo que son: meros posicionamientos políticos de la mayoría o la totalidad de los concejales, y no expresión acabada y monolítica de la opinión de todos y cada uno de los vecinos en relación con un determinado asunto.

\section{CONCLUSIONES}

1. El presente estudio se ha ocupado de la legalidad de las declaraciones simbólicas municipales sobre cuestiones que no son propiamente de su competencia. Entre las causas que propician estas declaraciones se han aventurado

72 Martínez López-Muñiz (2002: 680). 
cuatro: el compromiso político y el deseo de participación de los concejales, e, indirectamente, de los vecinos; la voluntad de los representantes políticos de recuperar y mantener visibilidad en un espacio público saturado de canales y mensajes; la voluntad de forzar el posicionamiento del rival político en asuntos que pueden erosionar su popularidad; y el interés de las cúpulas de ciertos partidos para promover una agenda política utilizando cualquier medio a su alcance, incluidos los órganos de gobierno municipales. Albergamos la esperanza de que ulteriores estudios politológicos y sociológicos se ocupen de las declaraciones simbólicas, a fin de determinar su prevalencia, describir a fondo sus características y explorar en detalle las causas que las originan.

2. Como se ha tenido ocasión de analizar, la jurisprudencia sobre declaraciones simbólicas es acusadamente inconsistente y casuística, lo que dificulta la identificación de criterios generales sobre la legalidad de una determinada declaración. Sea de ello lo que fuere, sí resulta posible apuntar algunos criterios indiciarios, que permiten intuir si una declaración es conforme a derecho. En principio, será más fácil que una declaración sea inválida si: 1) es susceptible de afectar a la esfera de derechos e intereses legítimos de los administrados; 2) tiene un contenido abiertamente contrario a la Constitución; 3) no está conectada con los intereses del municipio. Por el contrario, tendrá mayores visos de resultar legal aquella declaración que: 1) no afecte a la esfera jurídica de los administrados; 2) se limite a trasladar una petición a la Administración o poder competente en la materia; 3) esté directamente conectada con el círculo de intereses del municipio. De estos tres criterios, el más consistente es el relativo a la posible incidencia de la declaración en la esfera de derechos e intereses legítimos de los administrados.

3. El análisis jurisprudencial realizado permite concluir que la principal causa de discrepancias acerca de la validez de las declaraciones simbólicas radica en el disenso existente respecto del alcance de la autonomía local. Así, desde las tribunas más reacias a reconocer a los municipios una autonomía política plena se tiende a considerar abusivas las declaraciones simbólicas en materias ajenas al círculo de intereses del municipio; mientras que desde posiciones más favorables a la autonomía política plena de los municipios, se admite sin mayores cuestionamientos la actividad declamatoria municipal, siempre y cuando la misma adolezca de efectos jurídicos. Lejos de constituir un problema, esta falta de consenso puede resultar cómoda para los órganos jurisdiccionales, toda vez que les ofrece argumentos jurídicos con que justificar sus resoluciones en materia de declaraciones simbólicas, sea cual sea su sentido. El precio de esta incertidumbre, sin embargo, se abona en términos de seguridad jurídica por municipios y ciudadanos. Por ello, sería deseable que - de una vez por todas - el Tribunal Supremo esclareciera cuál es el alcance de la autonomía local —al menos en relación con las declaraciones simbólicas-, y pusiera fin al rosario de sentencias contradictorias que se vienen pronunciando en las cuatro últimas décadas. 
4. Ni la jurisprudencia ni la doctrina han atendido a dos motivos que, a nuestro entender, recomiendan restringir sensiblemente el recurso a declaraciones simbólicas por parte de los municipios. De un lado, dichas declaraciones implican una participación institucional de una Administración local en un debate público, lo que podría vulnerar los principios de neutralidad ideológica, pluralismo y legalidad que deben informar el quehacer de los poderes públicos, poniendo en jaque el mantenimiento de una opinión pública libre. De otro, las declaraciones simbólicas se justifican a menudo en base a una representatividad democrática de los concejales que, en aquellas materias que exceden las competencias municipales, no resulta claro que exista. En efecto, para cuestiones atribuidas a las comunidades autónomas, al Estado o la Unión Europea, los vecinos cuentan con otros representantes democráticos, que son quienes ostentan legitimidad para pronunciarse en nombre de sus electores, y cuyas posiciones no tienen por qué concordar con aquellas mantenidas por los representantes electos a nivel local. 
